\title{
"DIS POLITIKA" NEDIR? TÜRKIYE'DEKI DÜNÜ VE BUGÜNÜ
}

\author{
Doç. Dr. Omer KÜRKÇưoĞLU
}

\section{GIRIŞ}

\section{A. "Dış Politika"nın Tarihçesi}

"Dıs Politika" kavramı üzerinde ciddi bir biçimde düşünülmeğe başlanması ancak Birinci Dünya Savaşından sonradır. Ondan önce, Hükümdarlamn veya birkaç en yetkili kişinin tekelinde olan dış politika konusu, bir "tabu" niteliği gösteriyordu. İngiltere gibi Parlamento geleneği eski ülkelerde bile dış politika, üzerinde en az tartışılan alan durumundaydı. "İmparatorluğun yüce çıarları" öyle emrettiği için, dış politika üzerinde tartışmaya pek girilmezdi. Yine, İngiltere'de görüldüğü gibi, siyasi partiler başka konularda görüs aymlığı içinde olabildikleri halde, dış politika üzerinde genellikle çatışmazlar ve benzer politikaları uygularlardı. ${ }^{1}$ Sömürgeci devletler açısından bu durumun açıklaması kolay olsa gerekir. Ancak başka ülkelerde de dıs politika konusu, yukarıda belirtilen genel duruma uygun olarak; devlet başkanı, başbakan, dışişleri bakanı üçgeninin içinde kalırdı.

XX. Yüzyılın başlarında Birleşik Amerika'da Andrew Carnegie, savaşın yok edilmesi için bir fon kurmuştu. ${ }^{2}$ Ancak, araştırmalar sonunda 1911 yllında hazırlanan bir raporda, bunun yapllabilmesi için şunlann iyice bilinmesi gerektiği ortaya çıkıyordu :

1 "Muhafazakâr ve Liberal Partinin dıs politika çıkarlan (temel amaçlan) birleşmekte lidil...hizmetin en iyi şekilde görülebilmesi...her iki partideki önderlerin fikrine, politikanın, diplomasi hünerlerini bilen ustaların eline bırakıldığ ve...teknik bir iş olarak, halk önünde tartışmalardan uzak tutulduğu ölçüde mümkünldūl..."Mümtaz Soysal, D1S Politika ve Parlamento, D1̧ Politika Ala nındaki Yasama-Yürütme llişkileri Üzerinde Karşılaştırmalı Bir Inceleme, A.Ü. SBF Yayinlan, No. 183-165, Ankara, 1964, s. 44.

? Harry Howe Ransom, "International Relations", Political Science, Advunce of the Discipline (Ed. by Marian D. Irish), Prentice-Hall, Inc., N.J., 1968, s. 55. 
- ulusları harekete geçiren temeldeki etkenler

- bu hareketlerin yöntem ve hedeflerindeki gelişim

- uluslarnn birbirleriyle ilişkilerinin tarihi gelişimi.

Yani, kısaca, savaşı yok edebilmek için, uluslararası ilişkiler alanına bilimin el atması gerektiği görülüyordu. Ancak bunun gerçekleşmesi için ise kitlelerin yaygun biçimde bu gereğin farkına varması gerekiyordu.

İnsanlık, Birinci Dünya Savaşı ölçüsünde bir büyük, yani kitle savaşı yaşadıktan — savaşın yükünü yalnız cephede değil, her yerde çekmek zorunda kaldıktan- sonradır ki, dıs politika konusuna el atmak gereğini duydu. İngiltere'de olduğu gibi, dıs politikanın "gerçek bir tartışma konusu olarak" Parlamento'ya girebilmesi, "kitle demokrasisinin yerleşmesiyle birlikte, ayrıca kanlı bir Dünya Savaşının da geçirilmesinden sonra mümkün olabilecektir."3 Gizli diplomasinin ürünü olan gizli ittifak hükümlerinin, kendilerini hangi durumlara soktuğunu acı biçimde gören kitleler, dış politikayı birkaç kişinin tekelindeki bir yasak konu olmaktan çıarmak yoluna girdiler.

Önce Birleşik Amerika'da Devletler Hukukçular, hukukî bir yaklaşımla dıs politika alanına el atmağa başladılar. ABD'nde bu çerçevede çalışan bilim enstitüleri kuruldu. Zamanla diş politika, siyaset bilimcilerinin incelediği bir alan oldu. Başka ülkeler de diş politikayı yasak alan olmaktan çıkarmağa koyuldular.

Birincisinden çok daha yakıcı olan İkinci Dünya Savaşı, bu yoĺdaki çalışmaları daha da hızlandırdr. "Dış politika" konusunu inceleyen "Uluslararası İlişkiler" disiplini bu dönemde hızlı bir gelişim gösterdi. Özellikle 1945-1963 arasındaki yoğun Dünya olaylan sırasında çok sayıda kitap yayınlandi; araştırma enstitüleri kuruldu. Nazari ve pratik tahlil konularına ilgi arttı.

\section{B. Temel Kavramlar}

"Uluslararası İlişkiler" disipliniyle uğraşanlar, ya daha çok güç dengesini temel alan geleneksel (klâsik) yaklaşımla, ya da sosyal

3 Soysal, Dı९ Politika..., op. cit., s. 45.

4 Uluslararası flişkiler (savaş-barış) üzerine eğilme konusunda, 1945 öncesi dönem pek verimli olamad. Bu dönemin lki istisnai eseri sumlardır: Quincy Wright, A Story of War (Vols. I-II), University of Chicago Press, Chicago, 1942 ve Harold Lasswell, World Politics and Personal Insecurity, McGraw-Hill, N.Y., 1935. 
bilimlerin yeni yöntem ve tekniklerini kullanan davranış̧̧ı (modern) yaklaşımla dış politika olgusunu incelemeğe giriştiler. Birinci yaklaફım, yukarıda yer alan 1911 tarihli raporun ortaya koyduğu, bilinmesi gerekli üç unsurdan daha çok "tarihì gelişim" üzerinde durur. İkincisi ise, öteki iki unsura, yani "temeldeki etkenler" ve "yöntemler"e ağırlık verir. "Klâsik-Tarihî" yaklaşımla, "Modern-Davranış̧̧ı" yaklaşım arasındaki tartışmayl ${ }^{5}$ incelemeğe girişmeksizin, bazı temel ayrlliklara dokunmak yeterli olacaktır :

- Davranış̧̧ Okul, uluslararası ilişkilerin tümünü kapsayan bir teoriye ulaşılabileceği görüşündedir.

Geleneksel Okul ise böyle kavramsal bir kuramm elde edilemeyeceği inancindadır.

- Davranışçı Okul, felsefí bir çerçevede, sisteme dayalı çözümlemede ısrar etmektedir.

Geleneksel Okul ise, insanın, yetenekleri çerçevesinde, dünyayı gerçek ve gözle görülebilir yönleriyle çözümlemesine ağırlık vermektedir.

$\mathrm{Bu}$ yaklaşımların (teorilerin) hiçbiri tek başına uluslararası ilişkiler disiplinini bütün yönleriyle açıklamağa yetmemektedir ${ }^{6}$. Meselâ karar-alma sürecini temel alan kuram, veya niceliğe dayalı çözümleme, geleneksel yaklaşıma birçok yönden katkıda bulunmaktadır; ama yine de hiçbiri tek başına bïr büyük teori çapında değildir. Fakat her birinin, uluslararası olguların açıklanmasında birbirini tamamladığını kabul etmek doğru olur.

Uluslararası ilişkiler yaklaşımları üzerinde daha fazla durmayacağı. Fakat dört kavram üzerinde kısaca durmak gerekmektedir : Dış Politika, Uluslararası İlişkiler, Uluslararası Politika ve Diplomasi.

Diş Politika: Bu konuda birçok tanım yapılmıştır. Bunları şöyle özetleyebiliriz: Bir devletin başka bir devlete veya devletler ya da daha geniş anlamıla uluslararası alana karşı izlediği politikaya dış politika diyebiliriz.

5 Morton A. Kaplan, "The New Great Debate: Traditionalism vs. Sceince in International Relations", World Politics, Vol. XIX, No. 1 (Oct., 1966), ss. 1-20.

$6 \mathrm{Bu}$ konuda bkz.: Ransom, op. cit., s, 80'den: Martin Wright, "Why Is There No International Relations Theory?", International Relations, Vol. 2 (April, 1960). ss. $35-48,62$ ve David Vital, "On Approaches to the Study of International Relations", World Politics, Vol. 19 (July 1967), ss. 551-562. 
Uluslararası Ilişkiler : Devletlerin veya uluslararası kuruluşlann birbirleriyle temaslan, karşllklı etkilenmeleri.?

Dış Politika ile Uluslararası İlişkiler arasındaki ayrılık şöyle anlatılabilir : Bir ülkenin, kendi sınırlarnnın ötesine karşı izlediği politika, o ülke açısından "dış politika"dır; daha geniş bir açıdan (sistem açısından) bakıldığında ise bir "uluslararası ilişki"dir."

Uluslararası Politika: Uluslararası İlişkiler disiplininin asıl gelişmesini gösterdiği 1945 sonrası döneminin ürünü olan bu kavramı da şöyle özetlemek mümkündür : Ayr ayr devletlerin dış politikalarının birbirleriyle temasa geldiği uluslararası siyasi ilişkiler alanının, bu ayrı dıs politikalardan hem etkilenen hem de onlara etkide bulunabilen genel olgular.

Diplomasi: Dış ilişkilerin, dış politikanın yürütülme biçimine ilişkin kaidelerinin tümü.

Yukandaki üç kavramdan özellikle Uluslararası Politika nisbeten yeni bir kavram ${ }^{9}$ olduğu halde, Diplomasi eski Yunan'danberi var olagelen bir kurumdur.

\section{TURKIYE'DE "DIŞ POLITIKA" KAVRAMI}

\section{A. Geçmişteki Durum}

\section{Osmanlı Devleti Döneminde}

\section{a. Güçlü Döneminde}

Yukarıda dıs politika kavramı üzerinde ilmi açıdan durulmağa başlanmasının Birinci Dünya Savaşının sonrasına rastladığını söyledik. Dış Politika'nın Uluslararası İlişkiler disiplini altında incelenmesi yeni saylabilecek bir olgudur. Fakat dis politika olgusu, devletler arası ilişkilerde, devlet olgusuyla yaşıt biçimde var olagelmiştir.

"Yani, "uluslararası ilişkiler", uluslarnn "dıs politikalan"nın toplamından ibaret değildir; daha geniş çerçevede bir karşılıkh etkileşim süreci üzerinde durmaktadir. James E. Dougherty-Robert L. Pfaltzgraff, Jr., Contending Theorles of International Relations, J.B. Lippincott Co., Philadelphia-New York, 1971, ss. 25-26.

8 Fred A. Sondermann, "The Linkage Between Foreign Policy and International Politics". International Politics and Foreign Policy, A Reader in Research and Theory (Ed, by James N. Rosenau), 5th Printing, The Free Press, New York, 1867 , s. 11.

9 Ibid., s. 8. 
Tükiye'de "bugünkü", yani son 15 yıldan bu yana dış politika kavramindan ne anlaşıldığın incelemeden önce, Osmanlı Devleti dönemine kadar geriye gitmek mümkündür.

Osmanlı Devleti güçlü olduğu sürece diplomasiye hayatì önem vermek gereğini duymadı. Devlet, üstün askeri gücüne dayanıyordu. Başka devletlerle ilişkilerini de askeri gücü biçimlendiriyordu. Ancak, kuruluş döneminde, yani askerì gücü her alanda oluşuncaya kadar geçen sürede bazı devletlerle dostluk ilişkilerine (diplomasiye) özellikle önem verildiği görülür. Meselâ Osmanlı deniz gücünün henüz oluşmadığı başlangıç döneminde (XIV. yüzyılda) Osmanlı Devleti, denizlerde, güçlü Venedik'e karşı yine deniz gücü yüksek olan Ceneviz'le ilişkilerini iyi tutmağa özen gōstermiştir..$^{10}$

\section{b. Güçsüzleşme Döneminde}

XVIII. Yüzyıldan sonra Osmanlı Devleti'nin gücü zayıflamağa yüz tutunca, diplomasi de ön plâna geçmeğe başladı. Nevşehirli Damat İbrahim Paşa'nın Sadrâzamlığı sırasında (1718-1730) Avrupa gelişmelerini izlemek üzere 28. Mehmet Çelebi elçi olarak Fransa'ya gönderilmiş; ayrıca Viyana'ya da şehbender (konsolos) yollanmıştır. ${ }^{11}$ Osmanlı Devleti, ilk sürekli elçilerini de bu Yüzyılın sonlarında göndermiştir. ${ }^{12}$ XIX. Yüzyılın başlarında Yunan ayaklanması ve ardından Mısır Valisi Mehmet Ali Paşa'nın ayaklanması, bu temsilciliklerin kurulması (Avrupa'yla diplomatik ilişkilerin geliştirilmesi) faaliyetini bir süre için aksatmışsa da, olayların yatışmasından sonra yeniden hızlanmıştır. ${ }^{13}$

Diplomasi kurumunun bütün Avrupa'da gelişmeğe başlaması da aslında bu döneme rastlamakla birlikte, diplomasi artık Osmanlı Devleti için bir güvenlik aracı niteliğini almaktadır. Askeri güç zayıfladıkça, diplomasinin hayati önemi artmaktadır. Devletin güçlü olduğu dönemde yabancı devlet başkanlarına yazdıklän mektuplar-

10 Ismail Hakkı Uzunçarşılı, Osmanlı Tarihi, I. Cilt (Kuruluştan Istanbulun Fethine Kadar). Türk Tarih Kurumu Yayını, XIII. Seri-No. 16 (1), Ankara, 1947, ss. $117-123$.

11 Ismail Hakkı Uzunçarşılı, Osmanlı Tarihi, IV. Cilt. 1. Kısım (Karlofça Anlaşmasından XVIII. Yüzyılın Sonlarına Kadar), Türk Tarih Kurumu Yayını, XIII. Seri-No. 16 (d1), Ankara, 1956, s. 151.

12 llk sürekli Osmanlı elçiliģ̧i 1793 yllında Ingiltere devleti nezdinde kurulmuștu. Londra'ya gönderilen ilk sürekli Osmanlı Elçisi Yusuf Agăh Efendi idi. Hüner Tuncer, "Eski" ve "Yeni" Diplomasi, (SBF, Basılmamıs Doktora Tazi), Ankara, 1979, s. 73.

13 Abdurrahman Seref, Tarih-i Devlet-i Osmaniyye, Cilt II, Karabet Matbaas1, Istanbul, 1318 (1900), 8. 418. 
da ("nâmelerde") tepeden bakan ifadeler kullanan, yabancl elçilerin kabulünde benzer bir tutum gösteren Osmanlı Padişahlar, artık eşit davranma gereğini görmeğe başlıyorlard..$^{14} \mathrm{Bu}$ gelişmelerin ileri bir aşamasında, Haziran-Temmuz 1867'de Padişah Abdülaziz, özellikle Girit meselesinde Fransa'nın desteğini elde etmek amacıyla, önce Fransa'yı, sonra İngiltere'yi ziyaret etmiştir. Ziyaretin, hem Osmanlı Devleti, hem de Avrupa açısından önemi şuradaydı: "Osmanlı tarihinde, büyük istilâ hareketleri sayılmamak şartiyle ecnebi memleketlerinde seyahate çlkmış yegâne Padişah ve Hıristiyan memleketlerine dost olarak gitmiş yegàne Halife Sultan Abdülaziz'dir."15

Bu gelişmenin ilk ortaya çıtı̆̆ı̆ı dönemde (XVIII. yüzyılda), Avrupa devletlerinin aralarında birçok çekişmelerin (çeşitli nedenlerle uzun süreli savaşlarnn) olması, Osmanl Devleti'nin bir bakıma işine yaramıştır. Birbirleriyle uğraşan Avrupa deviletleri, zayıflayan Osmanlı Devleti'ne karşı ortaklaşa bir tutuma girememişlerdir. Hattâ, Avrupa devletleri, birbirlerine karşı oluşturduklan ittifaklara Osmanlı Devleti'ni de çekmek için zaman zaman yarış içinde bile olmuşlardır. Bu durum, Osmanlı Devleti'nin işini kolaylaştırmış ve daha uzunca bir süre ayakta kalmasına da yardımcı olmuştur. Dış gailelerden umumiyetle uzak kalınabilen bu dönemin tipik örneği Lâle Devridir.

Osmanlı Devleti, Avrupa sorunlarından uzak kalmağa çalıştıysa da, bu sorunlara bulaşmaktan yine de kendini kurtaramadı. OsmanII Devleti'nin, iç çekişmelerle de yoğunlaşan çöküşü hızlandıkça, birbirleriyle çatışan Avrupa ülkelerinin iştihası kamçlanıyor, her biri onu kendi çıkarına âlet etmek istiyordu. ${ }^{16}$ Kendi varlığını tek başına koruyamayacak duruma gelen Osmanlı Devleti, yine bu dönemde İsveç ve Prusya'yla ittifaklar yapmak zorunda kalyordu.

Öte yandan, Osmanlı Devleti, Avusturya ve Rusya'yla savaşların sürüklendiği gibi, nihayet 1789 Fransız Devrimi'ni izleyen çalkantılı dönem de Osmanlı Devleti'ni etkiledi. Fransa, 1798'de Osmanli Devleti'nin Mısır topraklarına saldırınca, ${ }^{17}$ Bâb-ı Âli, o kadar uzak durmağa çalıştığı Avrupa savaşlarına bulaşmış oldu. Avrupa sahnesinde Fransa'nın karşısında yer alan başlıca devletlerden İngiltere ve

14 Uzunçarşıl, Osmanlı Tarihi, IV. Cilt, 1. Kısım, op. cit., s. 171.

15 Ismail Hakkı Danişmend, Izahlı Osmanlı Tarihi Kronolojisi, Cilt: 4 (1703-1924), Ikinci Baskı, Türkiye Yayınevi, Istanbul, 1961, ss. 216-217.

16 Uzunçarşılı, Osmanlı Tarihi, IV. Cilt, I. Kısım, op. cit., s. 465.

17 Ayrıntılar için bkz.: Enver Ziya Karal, Fransa-Misır ve Osmanlı Imparatorluğu (1797-1802), Istanbul Ưniversitesi Yaymlan: 63, Edebiyat Fakültesi Tarih Semineri: VIII, Istanbul, 1938. 
Rusya, Osmanl Devleti'nin yardımina koştular. Osmanlı Devleti, 23 Aralik 1798'de Rusya'yla, 5 Ocak 1799 'da da. Ingiltere'yle ittifak imzaladi. Her iki devletin de yardımda bulunmasının kendileri açısından elbette nedenleri vardı. Fakat asıl mühim yönü, Osmanlı Devleti'nin bu tarihten sonra güvenliğini bir "denge politikası"na dayandırmağa başlaması oldu. Yani, güçlü bir devlete karşı bir başka güçlü devlete veya devletlere dayanmak, hattâ müttefiki olan devletleri de birbirlerine karşı oynamak biçiminde kendini gösteren "denge politikası", Osmanlı Devleti'nin ömrünü bir süre daha uzatan etkili bir unsur oldu.

Dı̧ politikanın, diplomasi ustalıklarının, Osmanlı Devleti bakımından böylesine önem kazandığı bu dönemde, dış ilişkiler konusu, yukarıda ele aldığımız gibi, Dünyadaki genel duruma da uygun biçimde, Hükümdar'ın ve onun Sadrazamı ile Dışişleri Bakanı'nın yetki alanından öteye taşmayan bir nitelik gösteriyordu. Osmanlı Devleti, Keçecizâde Fuat Paşa gibi gerçeketn usta diplomat Nâzırlara da sahip oldu. Zaten Batılı kaynakların da kabul ettiği bir gerçek suydu : Türkler, kritik coğrafî̀ mevkilerinin de bir gereği olarak, büyük devletlerin talanından, aynı zamanda ancak usta bir diplomasiyle kendilerini kurtarabilirlerdi. Osmanlı Devleti'nin, devamlı bir çöküş dönemi geçirmesine rağmen oldukça uzun bir süre yaşayabilmesinin önemli bir nedeni bu olmalıydı. Birçok Batılı yazarın, Türkler için "doğuştan diplomat" deyimini kullanması boşuna değildi.

Türklelr, iyi diplomat yetiştirmekte şanslı olabilirdi. Ancak, dış siyasî konularda etkili bir denetim -aşağıda temas edeceğimiz XIX. Yüzyıl sonlanndaki istisnaî ve kısa dönem dışında- Osmanlı Devleti'nde de elbette söz konusu değildi.

Osmanlı Devleti'nde, bütün çağdaş kurumlarıyla "iç siyaset" kavramı o kadar geç ve eksiklerle dolu bir olgudur ki, 1908 yilında II. Meşrutiyet'in ilânına kadar, "siyaset" deyince, "dış siyaset" anlaşıliyordu. Bu durumun bir göstergesi şudur: 1859'da kurulan Mekteb-i Mülkiye'de başındanberi okutulan ve dış olaylar tarihini anlatan "Tarih" dersi, 1908'den sonra "Siyasi Tarih" ("Tarih-i Siyasî") adını taşımağa başlamıştır. Bugün ise, "Türk siyasî tarihi"nden söz edildiğinde, artık "ic siyaset tarihi" anlaşılmaktadır.

Osmanlı Devleti döneminde dış politika olgusu, Hükümdar ve birkaç yüksek görevlinin tekelindeydi ama dış politika konulamnın (diş etkenlerin), memleketteki anayasa gelişmeleri (iç etkenler) üzerinde etkide bulunup, uzun dönemde dıs politika konusunun bir yasak alan olmaktan çımasını sağlayacak önemli bir dolaylı etkisi yi- 
ne de olmuştur. Gerçekten de Osmanlı Devleti'nde anayasa gelişmeleri, bu yolda yaygın bir kitle mücadelesinin adım adım elde ettiği başarılardan çok, Padişah'ın ve Devlet erkanının, XIX. Yüzyıl başlarından itibaren artan dış meseleler karşısında, Avrupa'daki güçlü liberal akımları ve bu fikirlerin güçlü temsilcisi olan büyük devletleri (özellikle İngiltere'yi) hoşnut etmek için bașvurdukları çäreler olarak da görülebilir. 1839 Tanzimat Fermanı'nın ilånı sırasında, Osmanlı Devleti, ayaklanan Misır Valisi karşısında âciz kalıp Avrupa'daki bu çevrelerin yardımına başvurmak zorunda kalmıştır. 1856 yılında Islâhat Fermanı yayınlandığı sırada da Osmanlı Devleti Rusya'ya karşı bir savaş vermiş ve bu savaşta yine İngiltere'nin desteğine dayanmıştı. 1876 yulında I. Meşrutiyet'in ilänında da, artan Balkan karışıklıkları karşısında yine aynı çevrelerin desteğini elde etmek ve Balkanlar'da kendisinden reformlar uygulaması istenilen Osmanlı Devleti'nin, kendisinin liberal bir yapıya kavuştuğunu göstererek bu baskılardan kurtulmak amaçlarnnın da rolü olsa gerekir. I. Meşrutiyet'in ilânının, İstanbul'da Balkanlar konusunu görüşmek üzere toplanan bir uluslararası konferansın başlangıc gününe (23 Aralık 1876) rastlatılması oldukça mànidardır. ${ }^{18}$ Mithat Paşa, açıkça söylememekle birlikte, federatif bir sistem kurmak ve Osmanl Devleti üzerindeki dış baskıları hafifletmek istiyordu. ${ }^{19}$ Ayrıca, özellikle Büyükelçi Ignatiyef'e, "Mutlakiyetçi Rusya'nın Anayasalı Osmanlı Devleti'ne müdahaleye hakkı olmadığı" söylenebilecekti.

Dış etkenin iç yapıyı etkilemesi Osmanl Devleti'nin daha sonraki dönemlerinde de, Cumhuriyet döneminde $\mathrm{de}^{20}$ görülmüştür.

1786 Anayasasıyla kurulan I. Meşrutiyet Meclisinde dış konularnn, istisnai bir biçimde enine boyuna tartışıldığı görülür. Zaten II. Abdülhamid de, 19 Mart 1877'de toplanan Meclis-i Mebusan'a gönderdiği mesajda, izlediği dış politikaya Meclis'i ortak etmek isteyen bir ifade kullanmıştı.

Başka ülkelerin Parlamento gelişmelerinde ilk ele alınan konular, para (vergi) ile ilgili olup, dıs politikanın eleştiriye uğraması çok

18 Bkz.: Fahir H. Armaoğlu, Slyasì Tarih, 1789-1960, Üçüncü Baskı, A.U. SBF Yayinlar No. : 382, Ankara, 1975, s. 268.

19 Siyasi tlimler Türk Derneği'nin Nisan 1878'da Ankara'da düzenlediği “Tūrk Parlamentoculuğunun tlk Yüzyıh" Sempozyumu'nda, 10 Nisan 1978 günü. Prof. Dr. Mümtaz Soysal'ın "I. Mesrutiyet Parlamentosu ve Dı̧ Politika" başlikh konuşması.

$20 \mathrm{Bu}$ konuda bkz. : Omer Kürkçüoğlu, "Türk Demokrasisinin Kuruluş ve Işleyişinde Dis Etkenler (1946'dan bu yana)", SBFD, Cilt. XXXIII, No: 1-2 (Mart-Haziran 1978), ss. 213-247. 
sonra vamlan bir aşama olduğu halde, I. Meşrutiyet Meclisi'nde dış konular ön plândadır. ${ }^{21}$ I. Meşrutiyet döneminde siyasi parti bulunmaması sonucu, parti disiplini gibi bir kavram da olmadnğndan, dış konularda çetin eleştiriler yapılabilmiştir. Hattâ Meclis'in kapatılmasınin temel nedeni de bu olmuştur.

Osmanlı Devleti o sırada Rusya'yla savaş halindeydi. Bu savaş sırasında Meclis'de Osmanlılık fikri güç kazanmaktaydı. Ilk Meclis'deki gayrı-müslim mebusların da Devletin bölünmezliğinden yana bir tutum almalarn ilgi çekicidir. "Meclis, Rusya ile savaş başladiğında, Osmanlı vatanseverliğinin örneği saylacak nutuklara sahne olmuştur."'22 Yani ilk Osmanl Meclis-i Mebusanı'nda -en geniş biçimde temsil edildikleri halde- azınlıklann milliyetçilik sorunu yarattığı ve II. Abdülhamid'in bu gerekçeyle Meclis'i kapattığı düşünülemez. ${ }^{23}$

Ancak, Meclis'in dış konulara yönelik bu "aşırı" ilgisi ${ }^{24}$ ve savaş gelişmelerinin çok sert eleştirilere uğraması karşısında, dış politikada hareket alanının kısıtlanacağı kaygısı, II. Abdülhamid'i çok etkilemiştir. Sonunda, önce Meclis'in yenilenmesi yoluna gidildi. Ocak 1878'de toplanan yeni Meclis, Şubat'ta "vakit kaybı (dış nedenler)" gerekçesiyle feshedilmiştir.

Padişah, ülkenin yeni bir ölüm-kalım savaşı içinde olduğu bir sırada dış siyasete yönelik eleştirilerden "rahatsızlık duymakta" o kadar haksız da sayılmazdı. Eleştiri kavramı -hele dıs konulara yönelik eleştiri kavramı - o kadar yeniydi ki, böylesine yoğun bir şekilde kullanılması, zaten Meşrutiyet'i gönülsüz kabul etmiş olan Padişah için bir fesih gerekçesi yaratmağa fazlasıyla yètti.

İstisnai diye nitelendirdiğimiz bu kısa dönemden sonra II. Meşrutiyet'e kadar, dış politika yeniden başlıca Padişah'ın tekelinde kald. II. Abdülhamid, "denge politikası"nda, yani bir büyük devleti ötekine karşı oynama işinde oldukça ustalıklı bir uygulama gösterdi.

21 Soysal, a.g.k. (adi geçen konuşma).

22 Ilber Ortayl, "Ilk Osmanlı Parlamentosu ve Osmanl Milletlerinin Temsili", Armağan (Kanun-u Esasinnin 100. Yilı). A.U. SBF Yayınları No.: 423, Ankara, 1878, s. 175 .

23 Ancak, Padişah, Avusturya-Macaristan Parlamentosu'nun 1886'dan sonraki gelişmelerinden kaygı duyup aynı durumun Osmanlı Devleti ıçin de ortaya çıkmasından çekinmiş olabilir. Ibid., s. 176.

24 Oyle ki. Rusya'ya karşı yürütülen savașta Ingiltere'nin de yardıma geleceği umularak, bu yolda bir mektup bizzat Meclis'ce hazırlanip bir mebusla Ingiliz Elçiliği'ne gönderilmişti. Soysal, a.g.k. 
Ancak, elbette Devletin, birtakım köklü sebeplere dayanan çöküşünün bir sonucu olan parçalanma durmadr.

II. Meşrutiyet'ten sonra dış politika konusu yeniden tartışma alanına çlkmıştır. II. Meşrutiyet Parlamentosu, iki bloka ayrılan Avrupa'da sürtüşmelerin arttığı bir dönemde, 17 Arallk 1908'de çalışmalarına başlamış ve "kendini, İmparatorluğun parçalanmasının hyz kazandığını gösteren bir dizi savaşların içinde bulmuştur." ${ }^{25} \mathrm{Bu}$ durumda, Parlamento'nun dış konuları yeni bir değerlendirmeye tâbi tutması güçleşiyordu. Bu zor ortamda, Parlamento, "dış politika güçlüklerini çözmek, hattâ İmparatorluğun toprak bütünlügünü korumak için 'dost büyük devletler'in yardımını sağlamak gibi artık gelenekleşen hükümet politikasını...biricik çııı̧ yolu olarak görmekten"26 öteye ister istemez gidemeyecektir. Parlamento, dıs siyasî konulara ayrıntılarıyla eğilmek yerine, ancak umumî nitelikteki tartışmalara ilgi göstermiştir. ${ }^{37}$ Zaten diş konularda yetişkinlikleri de olmayan Parlamenterler, aymca dı̧ sorunlan yürütme organının görevi sayma alışkanlığı içindeydiler. "Bunun da ötesinde, devletler arası ilişkilerin ayrnntılarına inildiğinde, bunun, yarardan çok zarar getireceğinden [de] korkulmaktaydı." ${ }^{28}$

Oysa, bu sefer siyasî partilerin de varlığı, dı̧̧ politika tartışmalarına yeni bir çap katabilirdi. Sonuçta, 1908-1914 arası, yine "denge politikası"nın gereği olarak, yeni bir dış dayanağın arayışı içinde geçti. Dönemin iki temel siyasi partisi olan İttihat ve Terakki ile Hürriyet ve İtilaf'dan birincisi daha çok Almanya ile ittifak yanlısı; ikincisi ise Ingiltere-Fransa yanlısıyd.

Osmanlı Devleti'nin, yaklaşan Birinci Dünya Savaşına hangi tarafta gireceği konusundaki siyasi tahteravalli oyunu, Alman yanl-- larının üstünlüğüyle sonuçlandı. Ancak, Osmanli Devleti'nin ve halkın kaderini bu kadár yakından ilgilendiren bir konuda verilen karar, yine çok dar bir zümrenin tekelinde kaldı. Öyle ki. Almanya'yla yürütülen ittifak görüşmeleri son aşamasına vardığında, Hükümetin bazı üyelerinin bu durumdan haberi bile yoktu. Kabine'deki Alman taraftarlan, başta Harbiye Nâzırı Enver Paşa, Padişah'ı da

25 Siyasi flimler Türk Derneği'nin Nisan 1976'da Ankara'da düzenlediği 'Türk Parlamentoculuğunun llk Yüzyıll" Sempozyumunda, 10 Nisan 1976 günü Prof. Dr. Serafettin Turan'ın, "II. Meşrutiyet Dönemi Parlamentosu ve Dıs Politika" başlıklı konuşması.

26 Idem.

27 Idem.

28 Idem. 
yanlarina çekerek Almanya'yla ittifakı elde ettiler. Osmanlı Devleti'nin daha sonra Savaşa girmesine yol açacak gelişmeler lözellikle Goeben ve Breslau adl Alman gemilerinin Çanakkale'ye sığınmaları ve bir müddet sonra da Karadeniz'deki Rus limanlarnn topa tutulması), yine büyük ölçüde yalnız Enver Paşa'nın bilgisi dahilinde geçen olup-bittilerdir.

\section{Kurtuluş Savaşı Döneminde}

Birinci Dünya Savaşı sonrasında, yani dıs politika kavramının bütün dünyada yasak konu olmaktan çıktığı bir sırada, Türkiye, biten Büyük Savaş kadar bir süre (1919-1922) yeniden savaş (Kurtuluş Savaşı) dönemi yaşadı. Üstelik bir yandan İstanbul'daki hükümet, öte yandan da Mustafa Kemal'in önderliğinde Anadolu'da oluşan siyasî güç, Kurtuluş Savaşı'nın yalnız dışa yönelik olmadığını; iç yönünün de bulunduğunu gösterir.

Bu dönemde Türkiye'de iki ayr dış politika izlenmektedir: Biri Padişah'ın ve İstanbul'daki hükümetin izlediği politikadır. Bu politika, İngiltere ve müttefiklerine karşı dostluk politikası izlenmesinden yanadur. Böylece Savaş'ta Almanya tarafinda yer almış olmanm "günahr"ndan kurtulmak ve müttefiklerin "af ve mürüvvetlerini" kazanmak mümkün olabilecekti. İstanbul'da dış politika konularını Birinci Dünya Savaşı sonrasının değişen ortamında tartışacak bir Meclis bile sürekli bir biçimde yoktu. Müttefikler, Mondros Mütarekesi'nden hemen sonra baskıyla Meclis'i feshettirmişler; 1920 başında yeniden seçilen Meclisi de iki ay kadar sonra bu sefer baskınla kapanmak zorunda bırakmışlardı. Bu durumda dıs politika konusunda alınan hayatî önemdeki kararları tartışacak, -hattâ birakınız tartışmayı- onaylayacak bir Meclis, dönemin hemen bütününde ortada yoktu. Padişah, bir anlamda üzerindeki sorumluluğu azaltmak için, Sevr Antlaşması'na doğru giden günlerde önde gelen kişileri davet ederek "Şûra-i Saltanat" oluşturmuş ama bu toplantılar göstermelik olmaktan öteye gidememiştir. O dönemin İstanbul'unda teslimiyetçi tutum yalnız Saray ve çevresine mahsus değildi. Bu tutum, basına da yansiyordu. Ancak Hukuk Fakültesi Dekanı Profesör Ahmet Selāhattin Bey gibi "Şûra-i Saltanat" toplantısına da davet edilmiş bir kişi -istisnaî olarak- izlenen dış politikaya karşı çıkan yazılar yazabiliyordu.

Savaş sonrası İstanbul'unun bu ortamında bir şeyler yapabilmenin imkânsızlığını gören Mustafa Kemal, kendisini Anadolu'ya gönderecek bir görevi Saray'dan ve Hükümet'ten ustalıkla elde etti. 
Mustafa Kemal'in dı̧ politika anlayışı, Osmanlı Hükümeti'ninkinden temel bir ayrillk gösteriyordu: XVIII. yüzynldanberi diplomasi, Osmanl Devleti'nin zayıflayan gücünü telâfi ederek ömrünü uzatmakta bir araç durumuna gelmişken, Mustafa Kemal, Devlet'in asıl dayanağının kendi gücü olması gerektiğini -birçok kere açıkça dile getirdiği gibịi- görmüştür. Anadolu'da mucizevî bir siyasì ve askeri teşkilâtlanmayı gerçekleştirmesi, adım adım köklü düzeltim ve değişimlere girişmesi, Mustafa Kemal'in Saray politikasından ne kadar farkh bir yaklaşımda olduğunu ortaya koyar. Mustafa Kemal bunu yaparken, diplomasiden de yararlanmağı ihmal etmedi. Hattâ bunu da İstanbul'dan çok daha iyi yaptı.

Mustafa Kemal, daha askeri öğrenciliği yıllarında, Devletin kurtuluşu üzerinde kafa yormuş ve ülkenin geniş imparatorluk sınurlarından vazgeçerek milli sınırlara dayalı bir yapıya kavuşması gereğine inançla sanlmıştır. Mustafa Kemal, Kurtulus Savaşı çıkınca, bu noktayı ve öteki dıs politika ilkelerini Misak-ı Millì'de topladı. Anadolu hareketinin, milli sınırlara dayalı ve tam anlamında bağımsız bir devlet olmaktan başka bir amaç taşımadığını açıkça ortaya koydu. Yani, Anadolu hareketinin birtakım serüvenler peşinde olmadığını; ama asgari isteklerinin de ne olduğunu açı seçik belirledi. Mustafa Kemal, dışarıda ve içeride çok kimse için imkânsız görünen bir işe, yani yeniden savaşa girerken uluslararası ortamı çok iyi değerlendirmesini de bildi. Diş politika olaylarına, ádetâ önzesiyle, ustalıklı bir yaklaşımı olan Mústafa Kemal, Dünya Savaşı sonrasının Avrupasının karşı karşıya bulunduğu yeni sorunları iyi teşhis ederek, Büyük Devletlerin yeni bir savaşa kolay kolay gidemeyeceklerini iyi kavradı. Üstelik bu devletler arasında çeşitli sorunların ve çekişmelerin bulunduğunu, eski İtilaf devletlerinin tâbir câizse "İhtilaf" devletlerine dönüştüğünü gördü. Bu çekişmelerden ustalikla yararlanmayı başardı. Ancak, bu kurnazca diplomasiyi Osmanlı Devleti'nin uzun süre yaptığı gibi olumsuz bir biçimde, yani çöküş nedenleri üzerinde durmadan yalnızca Devletin ömrünü biraz daha uzatmak için bir diplomasi cambazlığı biçiminde uygulamadı. Dünya'ya şunu gösterdi ki Anadolu hareketi sınırları belirtilmiş istekleri gerçekleşinceye kadar savaşacaktır; ama daha fazlasında gözü yoktur. Kaldı ki böylece gücünü ispatlamış ve çağdaşlaşma yolunda köklü adımlar atmağa da kararlı olan Anadolu'nun dostluğu, onunla savaşan Büyük Devletlerin de çıkarına olabilecektir. Mustafa Kemal, bir yandan tavizsiz savaşırken öbür yandan karşısındakilerle diyalog kapısını da açık bıraktı. İşte Kurtuluş Savaşı, Müttefiklerin Anadolu gerçeğini kabul etmeleriyle ve gücünü ispatlamış yeni Türkiye'yle 
dostluğun kendi çıkarlarına da uygun olduğunu görmeleriyle sonuçlanmış uzun ve yoğun bir mücadeledir.

Mustafa Kemal'in bu ustalıklı dıs politikasının oluştuğu Kurtuluş Savaşı yıllar, 23 Nisan 1920'de Ankara'da TBMM'nin açılmasından sonra dış politika konularının enine boyuna tartışıldığı bir dönem de olmuştur. Meclis oturumlannda temel konu dıs politikadur. Meclis tutanakları ve başlıca Nutuk'tań görüyoruz ki özellikle siyasí partinin oluşmadiğ ilk yıllarda Meclis'de zaman zaman en sert eleştiriler de yapılmıştır. Ölüm-kalım savaşı veren bir ülkede dış politika sorunları elbette temel konuyu oluşturacaktı. Mustafa Kemal'in diş politika üzerinde son söz sahibi olmasına rağmen bu eleştirilerden zaman zaman etkilendiği hattâ etkilemeğe çalıştığı görülmektedir.

1921 Anayasası diş konularda da yetkileri Meclis'in elinde topluyordu. Fakat, bu yetkileri, başta Meclis Başkanı olmak üzere Başbakan ve Dışişleri Bakanı eliyle kullanıyordu. Mustafa Kemal'in şahsi ağurlığı dış politikada kendisini baş yetkili durumunda tutmuştur.

\section{Cumhuriyetin Ilk Dönemi (1960'a kadar)}

\section{a. İkinci Dünya Savaşı Öncesi}

Kurtuluş Savaşından sonra kabul edilen 1924 Anayasasına göre, dış konularda - savaş ilânı, dı̧ ülkelere askeri kuvvet gönderilmesi gibi konularda- Meclis yetkili kllınmakla birlikte yürütme organının yetkileri de arttımlmıştır.

Kurtulus Savaşı'nın sona ermesinden sonra, dış konulamn Meclis'in temel konusunu oluşturması durumu, tabiatiyle, kendiliğinden sona ermiştir. Savaş hali sona erip de Türkiye Cumhuriyeti kurulunca, olağan devlet işleyişi içinde elbette dış konular baş köşeyi tutmaktan çlkmiştır. Gerçekten de, bu tarihten sonra, Türkiye'yi ilgilendiren diş sorunlar çözüme kavuşuncaya kadar, zaman zaman dı̧ konulamn ön plâna geçmesinden öteye sürekli bir dış ilgi söz konusu olmamıştır.

1923'den sonraki dönemđe Türkiye, yavaş yavaş Avrupa genel gelişmeleriyle de etkili bir biçimde ilgilenmeğe başlamıştır. Bu gelişmeler dolaylı, hattâ zamanla doğrudan biçimde Türkiye'nin güvenliğini de ilgilendirir nitelikteydi. Íki - Savaş - Arası (1919-1939) dönemi, orta güçteki devletlere etkinlik imkănı veren bir nitelik de taşıdığı için, Mustafa Kemal'in önderliğindeki Türkiye'nin o dönem Avrupasında saỵgı duỵulan bir ỵeri olduğu görülmektedir. 
Bu dönemde, dı̧ politika konusu yine başta Atatürk olmak üzere yürütme organının ilgili Bakanlarının ve bir ölçüde de yasama organının yetki alanına giriyordu. Dış politika üzerinde o dönemin dünyasında başlayan "tabuların yıkılması" yönündeki gelişme, Türkiye'ye henüz ulaşmış sayılamazdı. Dönemin basınında dış konuların oldukça geniş yer tuttuğu görülür. Ancak, dış politika konusunda Devletin izlediği politikaya karşı bir eleştiriden söz edilemezdi. Türkiye'de dıs konularda kamu oyundan, yani olayları yalnız izlemeyip hem de etkileyebilen bir etkenden söz edebilmek için daha uzun ylların geçmesi gerekecektir.

\section{b. İkinci Dünya Savaşı Dönemi}

Atatürk'ün ölümünden sonra İkinci Dünya Savaşı yılları, dış konuları ister istemez belirli yasaklar içinde tutan yeni bir kritik dönem oldu. Atatürk döneminin dış politikasına damgasını vuran nasll Atatürk'ün kendisi idiyse, İnönü döneminin dıs politikasının baş mimar da yine İnönü'nün kendisiydi. Atatürk hayattayken O'nun karar adamlığı yönünü ihtiyatlılığıyla dengeleyen "İkinci Adam" İnönü için Savaş yılları, çetin bir dış politika sınavı oldu. Atatürk'ün, Birinci Dünya Savaşına erken girildiği ve yeni bir savaştan ise Türkiye'nin uzak kalması gerektiği yolundaki görüşlerini yakından bilen İnönü, Türkiye'yi İkinci Dünya Savaşına girmekten kurtarmakla Atatürk'ün "dış politika vasiyetini" yerine getirmiş sayılabilir. Böyle bir politikayı uygulamak, İnönü'nün ihtiyatlı kişiliğine de uygundu. "Lozan Konferansını bütün güçlükleriyle yeniden yaşamamak" ilkesi, İnönü'nün bütün diş politika kararlarnna hâkim olmuştur denilebilir.

\section{c. Çoğulcu Demokrasiye Geçiş Dönemi (1945-1960)}

\section{(i) 1950'lerin Ilk Yarısina Kadar}

İkinci Dünya Savaşından sonra, Türkiye'de dıs politikayla ilgili önemli gelişmeler görüldü. Savaşın (hem Batı hem Sovyet) "demokrasi cephesinin" zaferiyle sonuçlanması Türkiye'de de çoğulcu demokrasi yönünde gelişmelerin hızlanmasını sağladı. Yani, yukarıda Osmanlı döneminden verdiğimiz örneklerde de görüldüğü gibi, yine bir dış etken ị̧ yapı üzerinde etkide bulunmuş oluyordu. Ayrıca öteki etkenlerin yainında, Türkiye'nin bazı Sovyet istekleri karşısında, Batı'nın (A.B.D.'nin) desteğine olan ihtiyacı da Batı tipi siyasî sisteme geçişte rol oynadı. Devlet Başkanı İnönü'nün bizzat yön verdiği gelişmeler sonucu 1945-46'dan itibaren Türkiye'de çok partili demokrasi yolunda huzlı adımlar atılmağa başladı. Bu gelişmenin Türki- 
ye'deki dış politika anlayışı bakımından asıl önemli yanı şuradaydı : Türkiye'de çok partili demokratik hayatın yerleşmesi, dış politika konusunda da çoğulculuk, yani yasakların gerçek olarak yłkılmağa başlaması demek olacaktı.

Ancak, 1945 sonrasının uluslararası ortamı, çoğulculuk yerine, iki kutuplu ve her biri içinde tekdüzelik gösteren bir yapıya bürünmekteydi. Böyle bir yapıda Türkiye'de - başka etkenlerin de etkisiyle- Batı'ya koyu bağlılık gösteren bir dış politika uygulaması adetâ kaçınılmaz hale geldiği için, bu politikayı eleştirmek gereği de pek duyulmayacak demekti. Kaldı ki, Türkiye'deki demokrasi gelişmeleri de uluslararası ortama uygun olarak gerçek çoğulcu bir yapıya kavuşamadı. Tersine, çoğunluk ilkesine dayalı seçim sisteminin de rolüyle, gittikçe artan bir iktidar baskısı ortaya çıtı. Yani, görünürdeki çok partili sistem, fiilen tek parti döneminin devamı biçimini almağa başladı. Hattâ, 1950'lerin ikinci yarısında uluslararası alandaki iki kutupluluk çözülmeğe yüz tuttuğu halde, Türkiye'deki iktidar baskısı daha da koyulaştı.

\section{(ii) 1950'lerin Ikinci Yarısında}

1950'lerin ikinci yarısında iktidar-muhalefet ilişkilerinin gerginleşmeğe başlamasından sonradır ki dış politika konusunda görüş aynlıkları da ortaya çıktı. Oysa, o tarihlere kadar, temel dış politika kararları Parlamento'da (ve kamu oyunda) hemen hiçbir tartı̧̧maya uğramadan alınabilmişti. Bazı çok önemli diş politika kararlannın (Türkiye'nin 1950 Haziranında çıkan Kore Savaşına, Birleşmiş Milletler kuvvetleriyle birlikte çarpışmak üzere askeri birlik göndermesi gibi) ise, özüne değil, alınış biçimine (Parlamento'ya haber verme zamanı açısından) eleştiri yöneltilmişti.

1950'lerin ikinci yarısında ise, Muhalefet, temelde köklü bir değişiklik öngörmemekle birlikte, iktidarın bazı dış politika kararlarına karşı çıkmağa ve bazı dıs olaylara karşı değişik yorumlar getirmeğe başladı. Bunun iki tipik örneği, 14 Temmuz 1958'de Irak'da monarşinin yıkılmasina yol açan devrim ile 5 Mart 1959'da Türkiye'yle Birleşik Amerika arasında yapılan ikili anlaşmaya karşı olan tutum ayrılıklarıdır. Birinci olayı, Hükümet, "dış tahriklerin bir sonucu" olarak nitelendirip, dolaylı biçimde Sovyetler Birliği ve Mısır'ı suçlarken, Muhalefet çevreleri ise, devrimi, "artan baskı ve istibdada karşı bir tepki". biçiminde değerlendirdi. Böylece Türkiye'de artan iktidar baskılanna karşı dolaylı bir protestosunu da dile getirmiş oluyordu. Bu tarihten sonra "ihtilâl" sözünün Türk siyaset tartışmalarma girmesi ve iktidarn, Muhalefeti, "Irak'daki benzer bir hare- 
keti Türkiye'de de gerçekleştirmek istemek"le suçlaması ${ }^{29}$ ilgi çekicidir. Bu gelişme, Muhalefetin iç politikada gittikçe anlaşmazlığa dùştüğü iktidarın dış politikasını da artık onaylamamağa başladığını gösteriyordu. İkinci örneğe gelince; Türkiye'yle Birleşik Amerika arasında imzalanan söz konusu anlaşmanın giriş bölümünde "dolaylı saldurı" ifadesine yer verilmiş olması, Muhalefetçe Meclis'de eleştiri konusu oldu: "Türkiye'deki Muhalefetin güçlenmesi olgusu, iktidar tarafindan, söz konusu anlaşmaya göre 'dolaylı saldırı' biçiminde nitelendirilecek olursa, anlaşma, demokratik yoldan bir iktidar değişikliğini önlemek için bile kullanılabilirdi." Türkiye'nin o ylllardaki gergin ortamında böyle bir kayginın duyulması mümkündü. T.B.M.M., 9.5.1960 günkü oturumunda anlaşmay, oylamaya katılan 308 milletvekilinin tümünün oylanyla onaylarken Muhalefet üyeleri oylamada hazır bulunmamışlardi..$^{30}$

\section{B. Bugünkü Durum (1960 Sonrasi)}

\section{1960'larin Ortalarina Kadar}

27 Mayıs 1960 Devrimi bu ortamda doğdu. Aslında Devrim, iktidardaki Demokrat Parti'nin dış politikasına doğrudan bir tepkinin sonucu olarak görülmemelidir. Devrimin nedenleri daha çok (iç) siyasal ve iktisadidir. Devrimi gerçekleştiern askeri yönetimin ilk açıklamalarında dış politikada bir değişiklik olmayacağı yolunda güvence verilmesi ilgi çekicidir. 27 Mayıs hareketinde Amerika'nın gizli desteği yolunda iddialar bulunduğu gibi, tersine 27 Mayıs'clların kendilerine karşı bir Amerikan müdahalesinden kaygı duydukları yolunda da görüşler bulunmaktadır. Eğer ikinci ihtimal doğruysa, 27 Mayıs'tan sonraki ilk açıklamalarda dıs politikada bir değişiklik olmayacağının vurgulanmasını anlamak daha kolaylaşabilmektedir.

27 Mayıs'tan sonra dıs politikada hemen önemli bir değişiklik ortaya çımadı. Belki bazı konularda daha esnek davranmak isteği belirmekteydi. Meselà, Cezayir Kurtuluş hareketine karşı daha anlaysşl bir tutumun ipuçlar görüldü. Sovyetler Birliği'yle de ilişkilerde normalleşme yolunda bir isteğin bulunduğu anlaşllıyordu.

27 Mayıs'ñ dış politika kavramı üzørindeki asıl etkisini, doğru-

29 Mesela, Başbakan A. Menderes, 14 Subat 1860'da Iskenderun'da yaptığı bir konuşmada, Irak thtilali'ne değinerek, Muhalefetin bu olaydan "ağizlarının sulandığını" ve "Türkiye'de de ayn mahiyette bir hareketin olması için zemin yaratmağa çalıştığını" söylüyordu. Cumhuriyet, 15 Şubat 1860, 8. 5.

30 TBMM Zabit Ceridesi, Cilt 13, Yll : 1960, TBMM Matbaas1, Ankara, 1960, s. 456. 
dan doğruya dış politika uygulamasında değil, etkisi uzunca dönemde görülecek birtakım yapı değişiklikleri yoluyla gösterdiğini görüyoruz. 27 Mayıs'ın getirdiği 1961 Anayasası, hem dış politika konularının Parlamento'da daha iyi denetilmesini sağlayacak siyasi kurumlaşma değişiklikleriyle, hem de asıl önemlisi, Türk siyaset hayatına yeni güçlerin katılmasını sağlayacak niteliklerinden dolayı katkıda bulunmuştur. 1961 yllında radikal sol nitelikli bir siyasì partinin de kurulmasıyla Türk demokrasisi yeni bir aşamaya ulaşmış oluyordu. Diş politikada köktenci değişikliklerin öne sürülmesi bu tarihlerde başlamaktadır. Yeni çımağa başlayan bazı yayın organlarında (meselâ, Yön dergisinde) Türkiye'nin o zamana kadar izlediği dış politika eleştirilmekte, Türkiye'nin Batı blokuyla ilişkiler yerine Üçüncü Dünya ülkeleriyle ilişkilere yönelmesi gerektiği savunulmaktaydr.

Türkiye'de bu değişimlør yaşanırken, uluslararası ilişkilerde 1950'lerin ikinci yarısındanberi görülen çözülme daha da ileri bir aşamaya varmış bulunmaktaydı. Bir yandan Üçüncü Dünya ülkelerinin sayısının hızla artmakta olması, öte yandan iki en güçlü devlet $\mathrm{ABD}$ ile SSCB arasında "zirve diplomasisi"nin güç kazanması ve bu gelişmenin hem nedeni hem de sonucu olarak her iki blokta da çözülmelerin hızlanması, uluslararası ilişkileri 1970'lerin başında ortaya çkacak yumuşama (détente) aşamasına hazırlamaktaydı. Yani, Türkiye'de dıs politika konularının enine boyuna tartışlmağa başlamasını sağlayan içerideki çözülme (plüralizm), dışarıdaki çözülmeyle paralellik içindeydi.

Dıs politika konusunda, yahut herhangi bir konuda, gerçek anlamında kamu oyundan söz edebilmek için, hem kitle haberleşme araçlarının yaygınlaşmasının hem de siyasî tartışma özgürlüklerinin varlığına ihtiyaç olduğu açıktır. İşte 1960'lardan itibaren Türkiye'de her iki bakımdan da ileri bir aşamaya varılmaktaydı.

Yine de, dıs politika konularındaki yeni tartışmaların başladığı ilk yllarda hemen yoğun bir kamu oyu ilgisinin doğduğu söylenemez. Bu tartışmalar, aydın kesim içinde kısıtlı bir alandan öteye pek ulaşamıyordu. Geniş kitlelerin, çeşitli nedenlerle -dış konuları izlemenin bir ölçüde uzmanlık gerektirmesi gibi nedenlerle- daha çok günlük hayatı ilgilendiren iç sorunlarla meşgul olduğu; dış konularla ise ancak kendisini doğrudan ilgilendiren bir (milli) sorun ortaya çıktığı zaman ilgilendiği genel bir doğrudur. Gerçekten Türkiye'de 1960'ların ilk yılları, 27 Mayıs'ın getirdiği (iç) siyasi sorunlarla -bu arada iki askeri därbe girişimiyle- dolu bir dönem oldu. Böylesine 
çalkantılı bir ortamda Türkiye'de geniş kitlelerin dıs politika konusunda başlayan eleştirilerle fazla ilgilenmesi her halde beklenemezdi. ${ }^{31}$ Tâ Türkiye'yi (Türk kamu oyunu) doğrudan ilgilendiren bir diş sorun ortaya çıkıncaya kadar.

\section{1960'larin Ortalarindan Sonra}

1963 sonunda Kıbrns sorununun yeniden bir bunalim dönemine girmesi, yarattığı sonuçlar bakımından bir dönüm noktası oluşturdu. Türkiye, o zamana kadar izlenen (1945 sonrası) dıs politikasının Türkiye'nin dıs güvenliğini tam anlamıyla gerçekleştirmediğini, üstelik Türkiye'yi dış alanda yalnızlığa ittiğini acı bir biçimde gördü. Türk dı̧ politikasını yeniden gözden geçirmek gereği Türk yönetici çevıelerinde açıklıkla hissedildi. Bu ortamda, özellikle 1964 yılında ABD Başkanı Johnson'un Başbakan İnönü'ye gönderdiği ve Türkiye'nin Kıbrıs'a yapmak istediği müdahaleyi baskıyla önlemeği amaçlayan ama bunu yaparken Türkiye'nin NATO'yla ve ABD'yle yillardır giriştiği işbirliğinin Türkiye'nin güvenliğini sağlayamabileceğini ortaya koyan mektubun 1966 yılı başında, yüksek tirajlı bir günlük gazetede (Hürriyet, 13 Ocak 1966) yayınlanması, kamu oyunun Türk dış politikası konusuna yoğun ilgi duymasını sağladı. 1960'ların ilk yllamnda başlayan ama kamu oyunun ilgisini çekemeyen dış politika eleştirilerini haklı gören ve gittikçe artan bir ilgi doğdu. Böylece, "dıs politika konusu yalnızca karar vericilerin dikkatini ve sorumluluğunu üzerinde toplayan bir konu olma niteliğini kaybetmiş, karar vericiler dışındaki vatandaşların ilgilendikleri, tartıştıkları ve kanaatlerini hem birbirlerine hem de karar vericiye duyurduklar bir konu durumuna gelmiştir."32 Daha önce yalnız genellikle solda yer alan yazarlar konuyu Kıbris sorunuyla sinirli tutmayıp genel olarak dış politika eleştirisi yaparken, ${ }^{33}$ artık tüm Türkiye'de "Amerika'nın davranışı Kıbrıs sorununun dışına taşarak genel Türk dıs politikası açısından incelenmeğe başlamıştır." 34

Kıbrıs konusu Türkiye'yi doğrudan ilgilendiren rastgele bir diş politika sorunu da değildi. Gerçek bir kamu oyu etkisinden söz edemeyeceğimiz 1950'lerin ikinci yarısında da Kıbrıs sorunu için gösteri

31 Oyle ki, bazı yazarlar dıs konulara karşı ilginin azaimasından yakınmaktaydı. Ornek: Duygu Sezer, Kamu Oyu ve Diş Politika, A.U. SBF Yayınlan No. 339, Ankara, 1972, s. 123'den: Y.K. Karaosmanoğlu, "Biraz da Dis Politika", Ulus, 30 Haziran 1960; Nadir Nadi, "Bir Seminer Toplantısi", Cumhuriyet, 30 Mart 1961 ve Cetin Altan, "Angola, Amerika ve Biz", Milliyet, 30 Mart 1961.

32 Sezer, Kamu Oyu..., op. cit., s. XIX.

33 Ibid., s. 204.

34 Ibid., s. 237. 
yürüyüşü ve mitinglerde bir kitle heyecanı yaşanmıştı. Halkın bildiği ve heyecanını daha önce yaşadığı bir diş sorununun 1960'larmn ortalarında yeniden alevlenmesi, Türkiye'nin yeni ortamında elbette böylesine derin yankular yaratacaktı.

$\mathrm{Bu}$ dönemde, gerek Sol'da, gerekse Sağ'da yer alan yazariar, basında, Türk dış politikası üzerinde, yani daha açık bir deyişle Türkiye'nin Batı'ya karşı o zamana kadar izlediği politika üzerinde yoğun bir tartışma açtılar. "Şahsiyetli dış politika", hem Sol'da, hem Sağ'da üzerinde en çok durulan kavram oldu. ${ }^{35}$ Sol'da yer alan bir yazar söyle diyordu :

“... Dış politikada yirmi yıldan beri kişiliğimizi, Batı Bloku içinde eritmiş bulunuyoruz. Batı Bloku içinde bulunmak başkadır; Batı Bloku içinde şahsiyetsizlik politikasına teslim olmak başkadir..."36

Batı aleyhtarlığı Sağ'ảa ise din açısından ele alınıyordu. Batı'nın, Kıbris konusunda "bize sırf Müslüman olduğumuz için cephe aldıklan" savunulmaktaydi. ${ }^{37}$

$\mathrm{Bu}$ ortamda ve iç ve diş etkenlerin, Kıbris sorunundan da bağımsız olarak vardığı yeni aşamada, dış konulara yönelik eleştiriler yoğunlaştığı gibi artık yalnız Türkiye'nin Ü Çüncü Dünya'yla yakınlığa yönelmesini istemekle de kalınmadı. Bu yıllar, ABD ve NATO aleyhtarlığının zamanla şiddet olayları niteliğini de alan yoğunluğa ulaştı̆̆ı bir dönem oldu.

1965 Ekimindeki genel seçimlerde radikal soldaki parti üyelerinin de Parlamento'ya girmesiyle, dı̧ politikaya yönelik köktenci görüşler böylece hem Parlamento'nun içinde hem de dişında etkili olmaktaydı. ${ }^{38}$ " 1965 yılı öncesi parti belgeleri ile 1965 sonrası parti belgeleri karşılaştırıldığında, dış politika konusuna ayrılan yerin büyüdüğü ve konularin incelenmesinde klişelerin ötesine çıkma eğiliminin belirdiği saptanmıştır." 39 Gerek siyasi partilerin kendi içinde, gerekse Parlamento'da dış politika konuları üzerindeki görüşmelerin arttığı ortaya çıkmaktadır. ${ }^{40}$

35 Ibid., s. 523. Dönemin òteki yaygın kavramlan, yine hem Sol'da, hem Sağ'da "Milli Menfaat-Ulusal Çıar" ile Sol'da "Bağımsız Dış Politika"dır.

36 Ibid., ss. 194-195'den, Ilhan Selçuk, "Dis ve Iç", Cumhuriyet, 2 Ocak 1964.

37 Sezer, Kamu Oyu..., op. cit., s. 201'den, Ahmet Kabaklı, "Hacl Richard", Tercüman, 30 Ocak 1964.

3 Sezer, Kamu Oyu..., op. cit., 8. 344.

39 Ibid., s. 345.

to Idem. 
Gerçekten 1960'larnn ortalarından itibaren Türkiye'nin "çok yönlü" dış politika uygulamasına giriştiği görülmektedir: $1963 \mathrm{Kibrıs} \mathrm{bu-}$ nalımindan sonra, 1964 yllı boyunca İnönü hükümetini "hareketsizlik"le suçlayan AP,41 1965 yulinda iktidara geçince "daha hareketli" olmak zorundaydı. Tabiîdir ki, bu "çok yönlü"lük, dıs politikanın oluşturulmasının da ilk defa gerçek anlamıyla "çok yönlü" bir etkenler şemasına ${ }^{42}$ kavuşmasıyla mümkün olmaktaydı. Türk dış politikasının oluşturulması, geleneksel olarak daha ziyade dıs etkenler ile sinırl sayıdaki iç etkenlerin (yöneticilerin felsefesi gibi) bir sonucuyken artık iç etkenlerin sayı ve ağırlığının arttığı görülmekteydi.

1971-1973 dönemi, iç yapıda nasıl sınırlayıcı etkiler yaptıysa, bunun tabii sonucu olarak diş politika tartışmalarına, yani dış politikayı oluşturan etkenlerdeki çoğulculuğa da bir sınırlama getirdi. 1973'den sonra çok yönlü ve çok etkenli diş politika dönemi yeniden işlemeğe başladi.

Dış politika konularının ilmì araştırma konusu edilmesi de 1960'ların ortalarından sonraki dönemde hızland. Uluslararası ilişkiler konuları gittikçe daha çok sayıdaki yüksek öğretim kurumlanında incelenmeğe başladı. Uluslararası İlişkiler Tarihi ("Siyasal Tarih") derslerinin yanısıra doğrudan doğruya uluslararası ilişkiler kuramlarını ve kavramlarını okutan dersler verilmeğe, Siyasal Bilgiler Fakültesi gibi, böyle bir dersi biraz daha önceden (1956'dan) bu yana programina koymuş bulunan okullarda da dersin kapsamı genişletilip bu konuda ayrica lisansüstü program uygulamasina geçildi.

Dış ilişkilerle uğraşan bilim enstitülerinin kurulması veya faaliyetlerinin çoğalması, hattâ yalnız üniversite yapısı içinde kalmayıp bir özel Dı̧̧ Politika Enstitüsü'nün Ankara'da kurulması da bu döneme rastlamaktadır. Öte yandan basında dış politika yorum ve haberlerinin artmasına paralel olarak, dıs politika yazarlarının bir dernek kuracak sayıya ulaşmaları yine bu dönemin gelişmelerindendir.

Dış politikayı oluşturan etkenler şeması göstermektedir ki belirli bir dış sorunun varlığı etkenlerden yalnızca bir tanesidir. Yani daha net bir ifadeyle, Kıbrıs sorunu Türk dış politikasını etkileyen etkenlerden yalnız biridir. Öyle olduğu halde, Türk dış politikasında 1960'larnn ortalarından sonra görülen olumlu gelişmelerde Kıbrns sorununun yarattığı tepkilerin temel rolü oynadığı da bir gerçektir. Özel-

4 tbid., ss. 172 vd.

22 Ek'tekt tabloya bakuniz. 
likle dıs konulardaki tabuların ylkilmasında, yani kamu oyunun dış politikaya karşı ilgisinin doğmasında böyle bir sorunun ortaya çıması zaten kamu oyu kavramının niteliğinden dolayı gerekliydi de. Kaldı ki, dünya olaylarına karşı geleneksel olarak yaygın bir ilgisizlik içindeki Türk kamu oyunun ${ }^{43}$ dış politikaya ilgi duyabilmesi için ancak onu böylesine doğrudan etkileyen bir dis sorunun ortaya çlkması gerekmekteydi.

1960'ların ortalarından başlayarak, dış politikadaki "çok yönlülüğün" temel etkenini oluşturan Kubrss sorununun çözüme kavuşmadan ortada kalmasının birçck olumsuz yönünün yanında olumlu bir yanının bile bulunduğunu söylemek yukarıdaki nedenle mümkün görünmektedir. Üstelik, Türkiye'nin Kıbrıs'a yıllardır yapamadığı askerî müdahaleyi 1974 Temmuz-Ağustos'unda gerçekleştirmesi, yani Cumhuriyet tarihinde 50 yl sonra ilk defa bir savaş durumunun ortaya çıması, Kıbris sorununun çapını arttırdığı gibi, halkın dıs konular üzerindeki duyarlılığını da yükseltti. Eylül 1974'ten sonra Kıbr1s sorunuyla bağlantılı başka sorunların ortaya çıması (ABD'nin silâh ambargosu gibi) ve bu yan sorunlarnn da halkın günlük yaşayışını yakından ilgilendiren birtakım iktisadi meseleler yaratması, bütün bu gelişmelerin dış konularla bağlantısını kitlelere canlı ve sürekli bir biçimde gösterdi.

Öte yandan, Türkiye, 1974 Kıbrıs müdahalesiyle büyük devletleri de ilgilendiren çok yönlü ve hassas bir konuda uluslararası sahnede ön plâna geçmiş oluyordu. Türkiye'nin dış politikasında o kadar önemli sonuçlar yaratan Kıbrıs konusu, rastgele bir dış konu değil; 1970'ler dünyasının birkaç çok önemli uluslararası sorunundan biriydi. Böylesine önemli bir konuda müdahale karamnı uygulayabilmek, elbette Türkiye'ye içeride güven, dişarıda ağırlık kazandırdı; ama sorunun uluslararası niteliğinden dolayı onu yoğun tepkilert de mâruz bıraktı. Bu da özel olarak Kıbrıs sorununa, genel olarak da dış politika konusuna karşı içte duyulan ilginin sürekli bir canlılık kazanmasinda etkili oldu.

Diş politika konusu üzerinde uzunca bir süredenberi düşünülmekte olması, gerek siyaset adamları ve yazarlar, gerekse genel olarak kamu oyu katında dış politikanın tepkilerden uzak değerlendirilmesine de katkıda bulundu. Türkiye'de 1970'lerle birlikte ABD ve NATO aleyhtarlığının 1960'ların sonlanndaki sertlik çizgisinden uzaklaşması, konularn daha serinkanlı bir biçimde ele alınmağa başladığının tipik göstergesidir. Türk dıs politikasındaki çok yönlülük uy-

13 Sezer, Kamu Oyu..., op. cit., s. 126. 
gulaması, Batı'dan ne kadar uzaklaşılabileceğinin, Doğu'ya ne kadar yaklaşılabileceğinin genel sınırlarını da ortaya çıkarmıştı. Yani Batı'yla ilişkilerin "asgari" çizgisiyle Doğu'yla ilişkilerin "azami" çizgisinin ne olabileceği, olması gerektiği, açıklık kazanmağa başlamıştı.

1970'lerin sonlanna gelindiğinde, Türkiye'nin temel bir dış politika ilkesinin, "Doğu-Batı yumuşamasını zedeleyecek davranışlardan uzak durmak" biçiminde ortaya çıması önem taşımaktadır. Bu ilkenin bir sonucu olarak, Türkiye, hem de demokratik solda yer alan bir siyasî partinin iktidarnda, NATO üyeliğini sürdürmenin gerekçesine ulaşmıştır.

Dış politika kavramının yukarnda yer alan çeşitli (Türkiye'ye ait) nedenlerle kitlelere mal olduğu bu dönemde Türkiye'nin bulunduğu Orta Doğu bölgesinin uluslararası ilişkilerdeki öneminin gittikçe artması, dıs politika konularını daha da günlük hayatın bir parçası haline getirdi. Aslunda, kitle haberleşme araçlarında yine de hâlâ dış olaylara yeterince yer verildiği söylenemezse de, gittikçe daha geniş bir kitleye ulaşılması, Türkiye'de dış konulara karşı belirli bir ilgi ve bilginin canlı tutulmasını sağlayabilmektedir. 1970'lerin sonlarında Türk dış politikasının çok yönlülük uygulaması, dış konularla gittikçe daha yakından ilgilenen bir kamu oyu önünde yapılmaktadir.

\section{GENEL DEGERLENDIRME}

Türkiye, bir yandan Avrupa kitasında toprağı bulunan tek İslàm ülkesi olması ve Batı'yla yüzyıllar boyunca bir etkileşim içinde bulunagelmesi dolayısıyla kaçınılmaz bir gereklilik olarak Batı'yla belirli bir ilişkiye sahip olmak zorundadır. Öte yandan, Türkiye, Sovyetler Birliği'yle de yüzyllar boyu süren ve mücadelelerle de dolu bir geçmişten kaynaklanan bir ilişkiye sahip bulunmaktadır. Bugün dünyanın en güçlü iki devletinden biri olan SSCB'yle sınır komşuluğu, dıs politikada ihtiyatlılığı gerektiren başlı başına bịr olgudur. Türkiye, Şovyetler Birliği'yle de ilişkilerini belirli bir çizginin altına düşürmemek zorundadır. Cumhuryet döneminin dış politikasının âdeta kurumlaşmış doğrultusu, yani Atatürk'ün dış politikası, Sovyetler Birliği'yle ilişkilerde ihtiyatlı ama belirli bir dostluk temeline dayanmıştır. Öte yandan, üçüncü olarak, Türkiye, geniş ölçüde bir Asya (Orta Doğu) ülkesidir de. Bu yönü, Türk toplumunun kültüründe, hattâ başta siyasi yapısında olmak üzere toplum hayatının birçok 
yönünde kendini belli etmektedir. Dolayısıyla, Türkiye, Üçüncü Dünyl ülkeleriyle ve öncelikle de komşusu Arap ve öteki İslâm ülkeleriyle yakınlığa da sahip bulunmalidır. Kaldı ki, Arap ülkelerine yakın bir dış politika, Türkiye'deki bütün siyasi güçlerin üzerinde birleştiği belki de tek dış konudur. Sol, özellikle bazı Arap ülkelerinin bağlantısızlık çizgisindeki Batı aleyhtarlığı dolayısıyla, Sağ ise hem din yakunlığı hem de iktisadi imkảnlar yönünden Araplara yakın bir politikayı desteklemiştir.

"Çok yönlü" dış politika, zaten bu üç güç merkezinin, yani Batı, Doğu ve Ựçuncü Dünya'nın her biriyle aynı anda iyi ilişkilere sahip olmak demektir. Yani, bu üç merkezin hiçbirine gözü kapalı bağımli olmayan fakat hiçbiriyle de ilişkiyi koparmayan bir politika izlemeği gerektirmektedir.

Böyle bir politikayı izlemek elbette zordur. Fakat Türkiye'nin "coğrafî determinizm"i bunu zaruri kılmaktadır. Denilebilir ki, böyle bir politikanın anlamı, hiçbir bloğun tam desteğinin garantili olamayacağı demektir. Hattâ, böyle çok yönlü bir politika, Türkiye'yi tam bir yalnızlığa da itebilir. Bu ihtimal, çok yönlü politikanın olumsuz sonucu olabilir. Bu politikanın olumlu sonucu ise, her üç güç merkezinin de Türkiye'yi daha fazla yanlarına çekebilmek için onun izlediği çok yönlü politikayı karşılıksız bırakmaması olabilecektir. Türkiye, objektif şartların zorladiğı böyle bir politikayı uluslararası alana iyi anlatabilmek zorundadır. Türkiye, NATO çevrelerinde herhangi bir Batı Avrupa ülkesinden farklı olan kendi şartlarını bir kenara bırakıp koyu bir NATO yanlısı görünümü alıp, Sovyetler Birliği yöneticilerine karşı ise NATO bağlantısını gizlemeğe ve önemini küçültmege çalışır, Üçüncü Dünya ülkelerine karşı da bağlantısız bir ülke görüntüsü almağa çabalarsa, elbette güvenilirliğini kaybeder ve sonunda tam bir yalnızlığa sürüklenebilir. Ama her üç güç merkezi önünde de, her biriyle iyi ilişkileri Türkiye'nin de istediği, zaten bunun Türkiye için bir zaruret olduğu, fakat hiçbiriyle de tam bir ayniyet içinde hareket edemeyeceği, çünkü bunun da imkânsız olduğu iyice ve sürekli anlatılabilirse, Türkiye kendisi için kaçınılmaz olan çok yönlü dış politikasından yarar elde edebilir. O zaman Türkiye, her ülke için dostluğu aranır ülke olur. Bunun anlamı şudur : Türkiye, Batı bloğu içinde kalarak, âdeta tarafsız bir ülke gibi etkili bir yere sahip olabilecektir. Türkiye'nin 1939 öncesindeki durumu burada hatırlatılabilir. O dönemde de Türkiye "çok yönlü" bir politika izliyordu. Hem Ingiltere cephesiyle, hem Sovyetler Birliği'yle, hem de Almanya'yla iyi ilişkilere sahipti. Bư ülkelerin hepsi de Türkiye'ye büyük önem veriyorlardı. 1939 yılında, yani hemen hemen 
herkesin yerinin belirlendiği bir tarihte bile, bu ülkelerin her birinin Türkiye'yi kendi saflarına almak için yarıştıkları görülmüştür.

Böyle hir politikayı izlemenin güç olduğunu yukarnda söyledik. Hüner, zor olanı yapabilmektir. Kaldı ki, "zor olan", yani çok yönlü bir dıs politika, yine yukarıda belirttik ki Türkiye için kaçınılmaz bir zarurettir. Yine de böyle bir politikayı izlemek özellikle belirli dönemlerde daha da güçleşebilecektir. Meselâ, 1945-1955 döneminin iki kutuplu dünyasında, yani dönemin niteliği gereği, üçüncü bir seçeneğin bulunmadiğı bir dönemde çok yönlü bir dış politika izlemek fiilen imkânsız sayılabilirdi. Üstelik, iki kutuptan biriyle Türkiye'nin güvenlik sorunlarının bulunması, "iki yönlü" bir politikayı da imkânsızlaştırıyordu. Dolayısıyla, Türkiye'nin 1945 sonrasında izlediği politikanın bu yıllara düşen dilimini anlayışla karşılamak gerekir. Yani, uluslararası ilişkilerin genel yapısı çok yönlülüğe imkân tanımiyorsa, Türkiye'nin kendi özel yeri öyle gerektirse bile, çok yönlü bir dış politika izlemesi fiilen imkànsız hattà gereksiz hale gelebilir. Ancak, Türkiye'nin yanlışı su oldu ki, 1945 sonrasının ilk on yllı için anlayışla karşılanabilecek Batı'ya koyu biçimde bağlı dıs politikasını, bir yandan Üçüncü Dünya olgusunun ortaya çıktığı, öte yandan da iki kutupluluğu eriten başka genel gelişmelerin doğduğu; üstelik Türkiye'yi Batı'ya bağlayan özel nedeninin (Sovyet tehdidinin) hafiflediği ikinci on ylllık dönemde de izlemeğe devam etmiştir. Böylece, hem uluslararası politikadaki gelişmelerin gerisinde kalan, modası geçmiş bir politikaya saplanılmış; hem de Türkiye'nin kendi özel durumunun zaten gerekli kıldığı çok yönlü bir politika zorunIuluğu yerine getirilmemiştir. Üstelik, bu gecikme, Türkiye'nin çok yönlü politika izlemeğe başladığı üçüncü ve hattâ halâ devam eden dördüncü on ylllık dönemde, karşısına birtakım engeller yığmıştır. Birçok Üçüncü Dünya ülkesi, Türkiye'nin 1955-65 dönemindeki yanhşlarını unutamamaktadır. Türkiye'yi o ylların gözüyle görmekten kendilerini kurtaramamaktadır. Hattâ, Türk dı̨̧ politikasındaki 1965 sonrası değişiklikleri, o sıralarda ortaya çıktığını hatırladıkları Kıbrns sorununun getirdiği pragmatik bir değişiklik olarak da görebilmektedirler. Türkiye, bunun böyle olmadığını, Kıbrıs sorununun sadece yanlışların farkına varılmasını sağlayan bir katalizör etkisi yaptığı gerçeğini iyi anlatmak zorundadır. Bunu yaparken güçlüklerle karşılaşması da kaçınılmazdır. Türkiye, 1955-65 döneminin olumsuz etkilerinden kolay kurtulamayacaktır.

1970'lerin sonlarnda gittikçe daha fazla kamu oyunun önünde yaşandığını yukanda söylediğimiz dıs politika olgusunun, yani çok yönlü dış politika uygulamasının başarı sağlayabilmesinin; büyük 
ustalık, sabır ve uzun zaman gerektirdiği ortaya çlkmaktadır. Böylesine zor bir politikayı uygulayacak yöneticilere ne kadar büyük bir sorumluluk düşüyorsa, kamu oyunu biçimlendiren kamu oyu yaratıcıları da o ölçüde büyük bir sorumluluk altına girmektedir. Duygularnna kolaylikla kaplabilecek kitlelerin gittikçe daha fazla önünde sergilenen çok yönlü dış politika uygulaması, sabırsız, dolayısıyla da haksız, eleştirilere uğrarsa yarar yerine zarar getirmeğe de başlayabilir. Hiçbir iktidar, artık kitlenin ilgi alanına girmiş dış politika alanında - ne kadar haksızca da olsa- eleştiri konusu olmayı kolay kolay göze alamaz.

Eylül 1979'da Havana'da yapılan 6. Bağlantısız Ülkeler Zirvesi Toplantısı'nda Kıbris konusunda Kıbrıs Rum yönetimini destekleyen bir kararın alınması Türkiye'de eleştiriler yarattı. Basında, üstelik dış konularda özellikle ağırlığı olan bazı yazarlar, Konferans'in Türkiye açısından olumsuz sonuç verdiğini görüp, Türkiye'nin çok yönlü dış politika uygulamasının "tam bir fiyaskoyla sonuçlandığı" kanısın dile getirdiler. Oysa, böyle bir hükme varmak, birçok bakımdan kendisi eleştiriyi hak etmektedir. Cünkü, her ne kadar, Kıbns konusu Türkiye'nin temel bir sorunu olup ikili ve çok taraflı uluslararası temaslardan sonra yaymlanan belgelerdeki yeri, Türk dış politikasının başar göstergesi olarak görülegeldiği halde, yine de Kıbrıs, Türk dıs politikasının tek etkeni değildir. Türk dış politikası, Kıbrıs konusunda veya herhangi bir doğrudan sorunda destek sağlamak için bir yol olmaktan ibaret değildir. Böyle bir sorun olmasa da, Türk dıs politikası, belirli ilkeleri ve davranışlan uygulamak zorundadır. Bu eleştiriler, üstelik, böylesine sabır isteyen bir dıs politika faaliyetinin birkaç yıl içinde olumlu sonuç vermesini istemek anlamı da taşımaktadır ki bu da yanlıs bir değerlendirme demektir.

Dıs politika kavramının bir yasak konu olmaktan çikmasının yararlarının görülmeğe devam edebilmesi elbette dış dünyanın ve onun içinde Türkiye'nin durumunun iyi öğretilmesine ve tabî̀ onun için de iyi öğrenilmesine bağlıdır. 


\section{YARARLANILAN KAYNAKLAR}

\section{Kitaplar :}

Allison, Graham T., Essence of Decision, Little Brown and Co., Boston, 1871.

Armaoğlu, Fahir H., Siyasĩ Tarih, 1789-1960, (Ưçüncü Bask1), A.Ư. SBF Yayınlar, No: 362, Ankara, 1975.

Danişmend, İsmail Hakkı, Izahlı Osmanl Tarihi Kronolojisi, Cilt : 4 (1703-1824), Ikinci Baskı. Türkiye Yayınevi, Istanbul, 1961.

Dougherty, James E. - Pfaltzgraff, Robert L. Jr., Contending Theories of international Relations, J.B. Lippincott Co., Philadelphia-New York, 1871.

Gönlübol, Mehmet, Dış Politika, İç Etkenler Açısından Bir Dış Politika Íncelemesi, Ulusal Basımevi, Ankara, 1968.

Karal, Enver Ziya, Fransa-Misir ve Osmanl Imparatorluğu (1797-1802), Istanbul Universitesi Yayınlan: 63, Edebiyat Fakültesi Tarih Semineri : VIII, Istanbul, 1938.

Sezer, Duygu, Kamu Oyu ve Dıs Politika, A.Ü. SBF Yayınlắ, No : 339, Ankara, 1972.

Soysal, Mümtaz, Dış Politika ve Parlamento, Diş Politika Alanındaki Yasama-Yürütme Illişkileri Üzerinde Karşılaştırmal ${ }_{1}$ Bir İnceleme, A.U. SBF Yayınlan, No: 183-165, Ankara, 1964.

Seref, Abdurrahman, Tarih-i Devlet-i Osmaniyyè, Cilt Il, Karabet Matbaası, Istanbul, 1318 (1900).

Tuncer, Hüner; "Eski" ve "Yeni" Diplomasi, (SBF, Basılmamı̧̧ Doktora Tozil, Ankara, 1879.

Uzunçarşılı, İsmail Hakkı, Osmanlı Tarihi, I. Cilt (Kuruluştan Istanbul'un Fethine Kadar), Türk Tarih Kurumu Yayın,, XIII. Seri-No: 16 (1), Ankara, 1947.

Osmanlı Tarihi, IV. Cilt, 1. Kısım (Karlofça Anlaşmasından XVIII. Yüzyılın Sonlarına Kadar), Türk Tarih Kurumu Yayını, XIII. Seri-No: 16 (d1), Ankara, 1856.

Makaleler :

Ataöv, Türkkaya, "Milletlerarası Münasebetler Nedir ve Üniversitelerde Nasıl Okutulabilir?", SBFD, Cilt : XV, Yll : 1960, No: 2, ss. 3-24.

Kaplan, Morton A., "The New Great Debate: Traditionalism vs. Science in International Relations", World Politics, Vol. XIX, No. 1 (Oct. 1968), ss. 1-20.

Kürkçüoğlu. Omer, "Türk Demokrasisinin Kuruluş ve Işleyişinde Dış Etkenler (1946'dan bu yana)", SBFD, Cilt: XXXIII, No: 1-2 (Mart-Haziran 1978), 86. 213-247.

Ortayl, Ilber, "Ilk Osmanl Parlamentosu ve Osmanh Milletlerinin Temsili", Armağan (Kanun-u Esasi'nin 100. Yill), A.U. SBF Yayınları, No: 423, Ankara, 1878, ss, 188-182.

Ransom, Harry House, "International Relations", Political Science, Advance of the Discipline, (Ed. by Marian D. Irish), Prentice-Hall, Inc. N.J., 1868, 8s. 55-81. 
Sondermann, Fred A., "The Linkage Between Foreign Policy and International Politics", International Politics and Foreign Policy, A Reader in Research and Theory (Ed. by James N. Rosenau), 5th Printing, The Free Press, New York, 1967, 8s. 8-17.

\section{EK}

\section{TƯRK DIŞ POLITIKASI'na YÖN VEREN ETKENLER}

\section{TABLOSU}

\section{DIS ETKENLER}

A. Dolaylı (Genel) Etkenler

1. Uluslararası Sistemin (Yapının) Etkileri

a. Siyasi Açıdan

b. Iktisadi Açıdan

2. Uluslararası Ideolojik Etkiler

3. Dıs Kamu Oyunun Etkileri

B. Doğrudan (Ozel) Etkenler

1. Belirli Bir Dıs Sorunun Olması

2. Coğrafi Konum-Bölge (Komşuluk) Sorumları

3. Uluslararası Bağlantılar
a. Siyasi Nitelikte
b. Iktisadi Nitelikte

II. IC ETKENLER
A. Milli Güç
B. Sosyal Etkenler (Toplum Yapisi)
C. Iktisadi Etkenler
D. Siyasi Etkenler

1. Yönetim Felsefesi (Kurumlaşmış Dış Politika Doğrultusu)

2. Resmi Kurumlar
a. Genel Olarak (Anayasa Yetki Dağllımı)
b. Siyasi Partiler
c. Ordunun Rolü (Millì Güvenlik Kurulu)
d. Dişişleri Teşkilàtı

3. Resmi Olmayan Kurumlar

a. Kamuoyu (Tarihi-Psikolojik Etkenler)

b Baskı Gruplan 